\title{
Birth Place Preference and Birth Attendant Selection during Covid-19 Pandemic in Tarakan City, North Kalimantan
}

\author{
Ririn Ariyanti, Ika Yulianti, Rahmi Padlilah
}

Department of Midwifery, Universitas Borneo Tarakan, Indonesia

\section{ABSTRACT}

Background: Childbirth assistance during the Covid 19 pandemic needs attention to reduce maternal mortality rate and infant mortality rate. This study aimed to analyze the factors influencing the choice of place and birth attendant during the Covid 19 pandemic in Tarakan City.

Subjects and Method: This was an observational analytic study with a case control design. The study was carried out in Tarakan, North Kalimantan, Indonesia, in 2020. A sample 100 pregnant women was selected by quota sampling. The dependent variable was the place and birth attendant. The independent variables were place of working, family income, distance to the place of delivery and knowledge. The data were collected by questionnaire using google form. The data were analyzed by a multiple logistic regression.

Results: The choice of place of delivery during the COVID-19 pandemic was influenced by place of working $(\mathrm{OR}=1.61 ; 95 \% \mathrm{CI}=1.49$ to 17.02; $\mathrm{p}=0.009)$, family income $(\mathrm{OR}=2.57$; $95 \% \mathrm{CI}=3.74$ to $45.37 ; \mathrm{p}<0.001)$, distance travel $(\mathrm{OR}=1.53 ; 95 \% \mathrm{CI}=0.07$ to $0.73 ; \mathrm{p}=$ $0.014)$ and knowledge $(\mathrm{OR}=1.66 ; 95 \% \mathrm{CI}=1.58$ to $17.31 ; p=0.007)$. The choice of birth attendant was also influenced by place of working $(\mathrm{OR}=1.32 ; 95 \% \mathrm{CI}=1.17$ to $12.40 ; \mathrm{p}=0.027)$, family income $(\mathrm{OR}=2.28 ; 95 \% \mathrm{CI}=2.94$ to 32.23; $\mathrm{p}<0.001)$, distance traveled $(\mathrm{OR}=-1.42$; $95 \% \mathrm{CI}=0.08$ to $0.78 ; \mathrm{p}=0.016)$ and knowledge $(\mathrm{OR}=1.88 ; 95 \% \mathrm{CI}=2.05$ to $20.85 ; \mathrm{p}=$ 0.002).

Conclusion: The choice of place and birth attendant is influenced by place of working, family income, distance traveled and knowledge.

Keywords: place of delivery, birth attendant, pandemic covid 19

\section{Correspondence:}

Ririn Ariyanti. Department of Midwifery, Universitas Borneo Tarakan. Jl. Amal Lama 1 Tarakan, Kalimantan Utara. Email: ririnariyanti.midwife@gmail.com. Mobile: +6285345553400.

\section{Cite this as:}

Ariyanti R, Yulianti I, Padlilah R (2021). Birth Place Preference and Birth Attendant Selection during Covid19 Pandemic in Tarakan City, North Kalimantan. J Matern Child Health. 06(01): 122-130. https://doi.org/10.26911/thejmch.2021.06.01.12.

cc) (7) (2) Journal of Maternal and Child Health is licensed under a Creative Commons Attribution-NonCommercial-ShareAlike 4.0 International License.

\section{BACKGROUND}

Inappropriate selection of places for delivery and birth attendants will have a direct impact on the delivery process, the most ideal place for delivery is a health facility with all the equipment and health personnel who are ready to handle in the event of an emergency in childbirth (Simkin et al., 2008). This is in accordance with the Ministry of Health's policy, namely to reduce $\mathrm{MMR}$ and IMR in Indonesia by encouraging that every delivery is assisted by trained health workers, namely obstetrics and gynecology specialists (general practitioners and midwives), to be carried out in health service facilities. This is in accordance with the 2015-2019 Ministry of Health's Strategic Plan which stipulates that delivery is assisted by health workers in health service facilities (PF) as an indicator of family health efforts to replace indicators of delivery assistance by health 
workers (PN) Deliveries assisted by health personnel in 2018 amounted to $90.32 \%$, while pregnant women who underwent childbirth assisted by health workers in health service facilities amounted to 86.28\% (Ministry of Health RI, 2019).

The results of the 2018 Riskesdas showed that the most widely used places of delivery were hospitals (both government and private) at $32.7 \%$ and the practice of health workers (health workers) was $29.6 \%$. However, home use is still quite high at $16.7 \%$, which is the third highest place for delivery. The government's recommendation for childbirth assistance in the mass of the Covid-19 pandemic is a planned referral for pregnant women at risk, mothers continue to give birth in health care facilities, immediately go to health facilities if there are signs of labor, mothers with COVID-19 cases will be managed according to management childbirths issued by PP POGI fiber postpartum family planning services continue to run according to predetermined procedures (Kemenkes RI, 2020). Based on the background description, the authors are interested in researching and knowing more about the factors that influence the choice of place and birth attendants in Tarakan City, North Kalimantan.

\section{SUBJECTS AND METHOD}

\section{Study Design}

This was an observational analytic study conducted in Tarakan City, North Kalimantan, in 2020.

\section{Population and Sample}

The population in this study consisteed of all women giving birth in Tarakan City. Sampling was done using a quota sampling technique. The subjects used were 100 subjects.

\section{Study Variables}

The dependent variable is place and helper of delivery. The independent variables are place of working, family income, distance traveled and knowledge.

\section{Operational Definition of Variables} The place of delivery is a place that is used for the delivery process with all the equipment and health personnel ready to handle in the event of an emergency in labor, the data scale is a dichotomy with a measurement result of $\mathrm{o}=\mathrm{BPM}, 1=$ clinic.

The choice of birth attendant is a decision to choose a birth attendant for the birth of a mother who gives birth, the data scale is a dichotomy with $0=$ midwife, $1=$ doctor.

Place of working is something that is done for a specific purpose which is done in a good and correct way, the data scale is categorical which for analysis purposes, the data is converted into a dichotomy with the measurement results $\mathrm{O}=$ inside the house, 1 $=$ outside the house.

Family income is the total income generated by the head of the family and the mother, either regular or side income in one month and expressed in rupiah currency values, the data scale is categorical which due to the need for data analysis is converted into a dichotomy with a measurement result of $0=$ low $(<\operatorname{Rp} 1,000,000), 1=$ high ( $\geq$ Rp 1,000,000).

Mileage is the distance required by the mother to reach the place of delivery.

Knowledge is the result of knowing from the mother regarding the place and birth attendant, the data scale is a dichotomous $\mathrm{O}=$ near, $1=$ far.

\section{Data Analysis}

Univariate analysis was carried out to see the frequency distribution and percentage of the characteristics of the study subjects. Bivariate analysis was carried out to study the relationship between choice of place and birth attendant with independent variables using the chi square. Multivariate 
Ariyanti et al./ Birth Place Preference and Birth Attendant Selection during Covid-19 Pandemic

analysis was performed using multiple logistic regression.

\section{Study Instrument}

Overall, variable data is measured by a questionnaire.

\section{Research Ethics}

Research ethics include informed consent, anonymity, confidentiality and ethical clearance, number 001 / KEPK-FIKES UBT / IX/2020.

\section{RESULTS}

\section{Sample Characteristics}

The subjects of this study were 100 mothers giving birth in Tarakan City, North Kalimantan. Based on table 1, the frequency

\section{Table 1. Sample Characteristics}

\begin{tabular}{lcc}
\hline \multicolumn{1}{c}{ Characteristics } & Frequency (n) & Percentage (\%) \\
\hline Place of working & 58 & 58.0 \\
At home & 42 & 42.0 \\
Outside of house & 50 & 50.0 \\
Family Income & 50 & 50.0 \\
Low & & \\
High & 50 & 50.0 \\
Mileage & 50 & 50.0 \\
Near & & \\
Far & 44 & 44.0 \\
Knowledge & 56 & 56.0 \\
Low & & \\
High & 47 & 47.0 \\
Place of Delivery & 53 & 53.0 \\
Private midwifery practice & & \\
Clinic (private, health center and hospital) & 47 & 47.0 \\
Birth attendant & 53 & 53.0 \\
Midwife & & \\
Doctor & & \\
\hline
\end{tabular}

\section{Bivariate Analysis}

Bivariate analysis was used to see the relationship between the independent variables (place of working, family income, distance traveled and knowledge) with the dependent variable (choice of place of delivery).

Table 2 shows a relationship between place of working and choice of place of delivery $(\mathrm{OR}=8.72 ; \mathrm{p}<0.001)$. Mothers who give birth who work outside the home distribution of the characteristics of the study subjects shows that almost half of the study subjects with mothers work at home, namely as many as 58 (58.0\%) subjects, most of them have low family income as much as 50 (50.0\%) and almost half of the study subjects has a long distance as much as $50(50.0 \%)$ and the characteristics of most mothers have high knowledge, namely as many as 56 subjects (56.0\%). Most of the places of delivery during the COVID-19 pandemic were in clinics (private clinics, community health center, hospitals) as many as 53 (53.0\%) and the last was the characteristics of birth attendants, namely doctors, as many as 53 (53.0\%). are 8.72 times more likely to choose a place of delivery in the clinic compared to mothers who give birth who work inside the home. There is a relationship between family income and choice of place of delivery $(O R=14.43 ; p<0.001)$. Maternity mothers who have high family income are 14.43 times more likely to choose a place of delivery at the clinic than mothers with low family income. 
Ariyanti et al./ Birth Place Preference and Birth Attendant Selection during Covid-19 Pandemic

There is a relationship between distance traveled and the choice of place of delivery $(\mathrm{OR}=0.20 ; \mathrm{p}<0.001)$. Mothers who gave birth with long distances were o.20 times more likely to choose a place of delivery at BPM compared to mothers who gave birth with long distances. There was a relationship between knowledge and choice of place of delivery values $(\mathrm{OR}=5.96 ; \mathrm{p}$ $<0.001)$. Mothers with high knowledge were 5.96 times more likely to choose the place of delivery in the clinic compared to mothers with low knowledge.

Table 2. Bivariate analysis of the relationship between work, family income, distance traveled and knowledge with the choice of place of delivery

\begin{tabular}{|c|c|c|c|c|c|c|c|c|}
\hline \multirow{3}{*}{$\begin{array}{l}\text { Independent } \\
\text { Variables }\end{array}$} & \multicolumn{4}{|c|}{ Selection of Place of Delivery } & \multirow{2}{*}{\multicolumn{2}{|c|}{ Total }} & \multirow{3}{*}{$\mathbf{O R}$} & \multirow{3}{*}{$\mathbf{p}$} \\
\hline & \multicolumn{2}{|c|}{$\begin{array}{c}\text { Private midwifery } \\
\text { pratice }\end{array}$} & \multicolumn{2}{|c|}{ Clinic } & & & & \\
\hline & $\mathbf{N}$ & $\%$ & $\mathbf{N}$ & $\%$ & $\mathbf{N}$ & $\%$ & & \\
\hline Place of working & & & & & & & & \\
\hline At home & 39 & 67.2 & 19 & 32.8 & 58 & 100 & 8.72 & $<0.001$ \\
\hline Outside home & 8 & 19.0 & 34 & 81.0 & 42 & 100 & & \\
\hline Income & & & & & & & & \\
\hline Low & 38 & 76.0 & 12 & 24.0 & 50 & 100 & 14.43 & $<0.001$ \\
\hline High & 8 & 18.0 & 41 & 82.0 & 50 & 100 & & \\
\hline Mileage & & & & & & & & \\
\hline Near & 14 & 28.0 & 36 & 72.0 & 50 & 100 & 0.20 & $<0.001$ \\
\hline Far & 33 & 66.0 & 17 & 34.0 & 50 & 100 & & \\
\hline Knowledge & & & & & & & & \\
\hline Low & 31 & 70.5 & 13 & 29.5 & 44 & 100 & 5.96 & $<0.001$ \\
\hline High & 16 & 28.6 & 40 & 71.4 & 56 & 100 & & \\
\hline
\end{tabular}

Table 3. Bivariate analysis of the relationship between work, family income, distance traveled and knowledge with the selection of birth attendants

\begin{tabular}{|c|c|c|c|c|c|c|c|c|}
\hline \multirow{3}{*}{$\begin{array}{l}\text { Independent } \\
\text { variable }\end{array}$} & \multicolumn{4}{|c|}{$\begin{array}{l}\text { Selection of birth } \\
\text { attendants }\end{array}$} & \multirow{2}{*}{\multicolumn{2}{|c|}{ Total }} & \multirow{3}{*}{ OR } & \multirow{3}{*}{$\mathbf{p}$} \\
\hline & \multicolumn{2}{|c|}{ Midwife } & \multicolumn{2}{|c|}{ Doctor } & & & & \\
\hline & $\mathbf{N}$ & $\%$ & $\mathbf{N}$ & $\%$ & $\mathbf{N}$ & $\%$ & & \\
\hline \multicolumn{9}{|l|}{ Place of working } \\
\hline At home & 38 & 65.5 & 20 & 34.5 & 58 & 100.0 & 6.97 & $<0.001$ \\
\hline Outside home & 9 & 21.4 & 33 & 78.6 & 42 & 100.0 & & \\
\hline \multicolumn{9}{|l|}{ Family Income } \\
\hline Low & 37 & 74.0 & 13 & 26.0 & 50 & 100.0 & 11.39 & $<0.001$ \\
\hline High & 10 & 20.0 & 40 & 80.0 & 50 & 100.0 & & \\
\hline \multicolumn{9}{|l|}{ Mileage } \\
\hline Near & 14 & 28.0 & 36 & 72.0 & 50 & 100.0 & 0.20 & $<0.001$ \\
\hline Far & 33 & 66.0 & 17 & 34.0 & 50 & 100.0 & & \\
\hline \multicolumn{9}{|l|}{ Knowledge } \\
\hline Low & 32 & 72.7 & 12 & $27 \cdot 3$ & 44 & 100.0 & 7.29 & $<0.001$ \\
\hline High & 15 & 26.8 & 41 & 73.2 & 56 & 100.0 & & \\
\hline
\end{tabular}

Table 3 shows that the results of the bivariate analysis are used to see the relationship between the independent variables (employment, family income, distance traveled and knowledge) with the dependent variable (selection of birth attendant).

There was a relationship between place of working and choice of birth attendant $(\mathrm{OR}=6.97 ; \mathrm{p}<0.001)$. Mothers who 
Ariyanti et al./ Birth Place Preference and Birth Attendant Selection during Covid-19 Pandemic

give birth who work outside the home are 6.97 times more likely to choose a doctor as birth attendant compared to mothers who give birth who work inside the home. There is a relationship between family income and choice of birth attendant $(\mathrm{OR}=11.39 ; \mathrm{p}$ $<0.001)$. Maternity mothers who have high family income are 11.39 times more likely to choose a doctor as birth attendant than mothers with low family income.

There is a relationship between distance traveled and the choice of birth attendant $(\mathrm{OR}=0.20 ; \mathrm{p}<0.001)$. Mothers who give birth with long distances are 0.20 times more likely to choose a doctor as birth attendant compared to mothers who give birth with long distances. There was a relationship between knowledge and choice of birth attendant (OR= 7.29; p <0.001). Maternity women with high knowledge were 7.29 times more likely to choose a doctor as birth attendant compared to mothers with low knowledge.

\section{Multivariate Analysis}

The results of multivariate analysis based on table 4 indicate a relationship between work and the choice of place of delivery. Mothers giving birth with jobs outside the home increased the likelihood of choosing a place of delivery at the clinic $(\mathrm{OR}=1.62$; $95 \% \mathrm{CI}=1.49$ to $17.02 ; \mathrm{p}=0.009$ ). The relationship of family income with the choice of place of delivery, mothers with high income increased the likelihood of choosing a place of delivery at the clinic $(\mathrm{OR}=2.57 ; 95 \% \mathrm{CI}=$ 3.74 to 45.37 ; p <0.001). The relationship between mileage and the choice of place of delivery, mothers with long distances traveled increased the likelihood of choosing a place of delivery at the clinic $(\mathrm{OR}=1.53$; 95\% CI $=0.07$ to $0.73 ; \mathrm{p}=0.014)$. The relationship of knowledge with the choice of place of delivery, mothers with high knowledge increased the likelihood of choosing the place of delivery in the clinic $(\mathrm{OR}=1.66$; $95 \% \mathrm{CI}=1.58$ to $17.31 ; \mathrm{p}=0.007$ ).

Table 4 The results of the analysis of the factors that influence the choice of place of delivery

\begin{tabular}{lcccc}
\hline \multirow{2}{*}{ Selection of Place of Delivery } & \multirow{2}{*}{ OR } & \multicolumn{2}{c}{ 95\% CI } & \multirow{2}{*}{ p } \\
\cline { 3 - 4 } & & Lower Limit & Upper Limit & \\
\hline Place of working (outside home) & 1.62 & 1.49 & 17.02 & 0.009 \\
Family Income (high) & 2.57 & 3.74 & 45.37 & $<0.001$ \\
Mileage (far) & 1.53 & 0.07 & 0.73 & 0.014 \\
Knowledge (high) & 1.66 & 1.58 & 17.31 & 0.007 \\
N observation=100 & & & & \\
-2 log likelihood=74.29 & & & \\
Nagelkerke $\mathrm{R}^{2}=0.63$ & & & \\
\hline
\end{tabular}

Table 5 The results of the analysis of the factors that influence the selection of birth attendants

\begin{tabular}{lcccc}
\hline \multirow{2}{*}{ Selection of birth attendants } & \multirow{2}{*}{ OR } & \multicolumn{2}{c}{ 95\% CI } & \multirow{2}{*}{ p } \\
\cline { 3 - 4 } & & Lower Limit & Upper Limit & \\
\hline Working place (outside home) & 1.34 & 1.17 & 12.40 & 0.027 \\
Family Income (high) & 2.28 & 2.94 & 32.23 & $<0.001$ \\
Mileage (far) & 1.42 & 0.08 & 0.77 & 0.016 \\
Knowledge (high) & 1.88 & 2.05 & 20.85 & 0.002 \\
\hline
\end{tabular}

The results of multivariate analysis based on table 5 indicate a relationship between work and the selection of birth attendants. Mothers giving birth with jobs outside the home increased the likelihood of choosing a birth attendant at the doctor $(\mathrm{OR}=1.34$; 95\% $\mathrm{CI}=1.17$ to $12.40 ; \mathrm{p}=0.027$ ). The relationship of family income with the selection 
of birth attendants, mothers with high income increased the likelihood of choosing birth attendant at a doctor $(\mathrm{OR}=2.28 ; 95 \%$ $\mathrm{CI}=2.94$ to 32.23 ; $\mathrm{p}<0.001)$. The relationship between mileage and selection of birth attendants, mothers with long distances traveled were more likely to choose birth attendant at the doctor $(\mathrm{OR}=-1.42 ; 95 \%$ $\mathrm{CI}=0.08$ to $0.77 ; \mathrm{p}=0.016)$. The relationship of knowledge with the selection of birth attendants, mothers with high knowledge were more likely to choose birth attendant at the doctor $(\mathrm{OR}=1.88$; $95 \% \mathrm{CI}=$ 2.05 to $20.85 ; \mathrm{p}=0.002$ ).

\section{DISCUSSION}

1. The influence of occupation with the choice of place and birth attendant

The results showed that there was an influence between work on the choice of place and helper with cesarean delivery. Abdurrahim et al. (2016) explained that work is related to the choice of place and birth attendants. Work is related to economic factors, which plays an important role in ensuring pregnant women's health, especially mothers who work outside the home. Health personnel have not been optimal in providing information about the choice of place and birth attendants, causing mothers with various characteristics to have low knowledge of choosing places and birth attendants. One of the characteristics that plays a role is work that is directly related to family income, especially to meet costs facing labor. Health personnel must embrace pregnant women in order to avoid the risk of danger and risk of death (Fitrianeti et al., 2018).

\section{The influence of family income and the choice of place and birth attendant}

The results showed that there was an effect of family income with the choice of place and birth attendant. The results of this study are in line with Putri (2016), which also shows that family income is one of the factors related to the choice of place and birth attendants. Family income is important in meeting basic and primary needs, including the need for preparation for pregnancy, childbirth and childbirth and possible complications that can occur during pregnancy and childbirth. In addition, mothers with high family income will find it easier to fulfill their needs in access to health services for early detection of health problems so that the health of the mother and fetus can be monitored optimally, Kimani et al. (2020) explain that childbirth during the COVID-19 pandemic requires serious attention, especially to reduce maternal and infant mortality and morbidity, there is an urgent need for innovative strategies to prevent worsening maternal and child outcomes, especially preventing the marginalization of childbirth at low family income levels, low family income can affect the choice of place and birth attendant which is positively related to the mobility rate due to the lack of optimal handling. It takes a comprehensive effort in the field of community based midwifery to avoid adverse problems for mothers and babies. The high burden of hospitals in handling covid 19 patients must get attention, especially for handling childbirth and preventing the risk of covid 19 transmission.

\section{The effect of distance traveled on the choice of place and birth attendant}

The results showed that there was a relationship between medical history and cesarean section delivery. Mwilike et al. (2018) explained that health facilities are one of the factors that affect the management of childbirth, the long distance is a factor that plays a role in decreasing the number of 
visits to health facilities. Maternity mothers must get optimal service, besides that, health priorities, both physical and emotional during the Covid 19 pandemic, must also get attention. The safety of mothers and babies is a top priority in handling childbirth so that an effective strategy is needed for handling childbirth during the Covid 19 pandemic. The results of Lail and Sufiawati (2018) reported that distance is not related to the selection of labor personnel, this is partly due to most of the study subjects have a short distance of 1-2 km to health facilities. Another factor that also influences is the support of husbands and health workers and health insurance. Adequate health service facilities and service accessibility must be in accordance with the 2015-2019 Ministry of Health Strategic Plan stipulating delivery assisted by health workers in health service facilities (PF) as an indicator of family health efforts to replace indicators of delivery assistance by health workers (Kemenkes RI), 2019).

Facilities and service accessibility during the Covid 19 pandemic were lacking and limited, especially related to childbirth services, lack of staff, or limited access to ambulance facilities which could not have an effect on delivery services during a pandemic, in addition because of long distances that reduced maternal visits to health facilities. Improved facilities and accessibility can reduce the risk of complications for mothers and babies, both those who give birth at BPM and clinics (Midwifery, 2020).

\section{The influence of knowledge on the choice of place and birth attendant}

The results showed that there was an effect of knowledge on the choice of place and birth attendants. Knowledge is an important factor that affects pregnant women, especially in choosing a place and a helper during the delivery process. Low healthrelated information affects the knowledge of mothers about childbirth which has an impact on negative attitudes towards the handling of delivery in health facilities. Delivery centers and birth attendants must have appropriate standards to reduce the risk of maternal and infant mortality, besides that knowledge related to COVID19 during pregnancy should be done to prevent complications due to being infected with Covid 19 and ensure that pregnant women are in good health (Zhao et al., 2020). The results of this study are in line with Hidra et al. (2017) which shows that knowledge is related to the selection of birth attendants which is statistically significant, mostly $56.8 \%$ of mothers choose health workers as birth attendants with high knowledge, the lack of knowledge of mothers regarding birth attendants can affect the mindset and decisions of birth attendants. from health workers or nonhealth workers (dukun). Mothers have the opinion that childbirth is natural and not dangerous because of the mother's ignorance regarding the danger signs of childbirth besides that the support from family and peers can relate to the mother's knowledge and play a role in the mother's decision making regarding the place and assistance of childbirth.

Maternal knowledge regarding the choice of place and helper is needed, difficult decisions must be made so that mothers need support to determine the place and birth attendant during the Covid 19 pandemic as well as knowledge of the efforts that the mother should make if infected with Covid 19. This includes the real location of midwifery causing the center birth to a triage center for pregnant women who present with symptoms of COVID 19 (Midwifery, 2020). 
Ariyanti et al./ Birth Place Preference and Birth Attendant Selection during Covid-19 Pandemic

\section{AUTHOR CONTRIBUTION}

Ririn Ariyanti, as the main researcher has a role in collecting and processing research data; Ika Yulianti and Rahmi Padlilah examined the conceptual framework and research methodology.

\section{CONFLICT OF INTEREST}

There is no conflict of interest in this study.

\section{FUNDING AND SPONSORSHIP}

This study uses the costs of a research grant.

\section{ACKNOWLEDGEMENT}

We thank to pregnant women who were participated in this study.

\section{REFERENCE}

Abdurrahim MA, Himawan AB, Wiyati PS (2016). Faktor-Faktor yang berhubungan dengan pemlihan tempat bersalin pada ibu hamil (studi kasus di Kelurahan Rowosari, Kecamatan Tembalang, Kota Semarang (Factors related to the choice of place of delivery for pregnant women (case study in Rowosari Village, Tembalang District, Semarang City). Jurnal Kedokteran Diponegoro. 5(4): 1214-1224. https://doi.org/10.14710/dmj.v5i4.14811.

Fitrianeti D, Waris L, Yulianto A (2018). Faktor yang mempengaruhi ibu hamil memilih penolong persalinan di wilayah kerja Puskesmas Malakopa Kabupaten Kepulauan Mentawai (Factors affecting pregnant women choosing childbirth attendants in the work area of Malakopa health center Mentawai Islands District). J Rehabil Res Dev. 2(3): 153-162. https://doi.org/10.22435/jpppk.v2i3.126.

Hidra, Majid R, Rasma (2017). Faktor yang berhubungan dengan pemilihan tena- ga penolong persalinan di wilayah kerja puskesmas Pasir Putih Kabupaten Muna tahun 2016 (The factors that to the election of delivery helper in working area of pasir putih health center year 2016 Muna). Jimkesmas. 2(6): 1-11. http://dx.doi.org/10.37887/jimkesmas.v2i6.2915.

Kemenkes RI (2019). Profil kesehatan Indonesia 2018 (Indonesia health profile 2018). Jakarta: Kementrian Kesehatan Republik Indonesia.

Kemenkes RI (2020a). Pedoman bagi ibu hamil, ibu nifas, dan bayi baru lahir selama social distancing (Guidelines for pregnant women, post-partum mothers and newborns during social distancing). Jakarta: Kementrian Kesehatan Republik Indonesia.

Kimani RW, Maina R, Shumba C, Shaibu S (2020). Maternal and newborn care during the COVID-19 pandemic in Kenya: recontextualising the community midwifery model.Hum Resour Health, 18:75. doi. 10.1186/s12960020-00518-3.

Lail NH, Sufiawati W (2018). Pemilihan tenaga penolong persalinan di Desa Panancangan Kecamatan Cibadak Kabupaten Lebak (Selection of birth attendants in Panancangan Village, Cibadak District, Lebak Regency). JAKHKJ, 4(1).

Coxon K, Turienzo CF, Kweekel L, Goodarzi B, Brigante L, Simon A, Lanau MM (2020). The impact of the coronavirus (COVID-19) pandemic on maternity care in Europe. Midwifery, 88: 102779. https://doi.org/10.1016/j.midw.2020.102779.

Mwilike B, Nalwadda G, Kagawa M, Malima K, Mselle L, Horiuchi S (2018). Knowledge of danger signs during pregnancy and subsequent healthcare seeking actions among women in 
Ariyanti et al./ Birth Place Preference and Birth Attendant Selection during Covid-19 Pandemic

Urban Tanzania: a cross-sectional study. BMC Pregnancy Childbirth. 18 (1):4. doi. 10.1186/s12884-017-16286.

Putri MD (2016). Faktor - faktor yang berhubungan dengan pemilihan tempat persalinan (Factors - factors related to the choice of place of delivery). Kesmas, 4 (2). doi. https://ejournal3.undip.ac.id/index.php/jkm/article/view /11926.

Riset Kesehatan Dasar(Riskesdas) (2018). Badan Penelitian dan Pengembangan Kesehatan (Health Research and
Development Agency). Kementerian RI tahun 2018.

Simkin P, Whalley J, Keppler A (2008). Panduan lengkap kehamilan, melahirkan dan bayi (Complete Guide to Pregnancy, Childbirth and the Baby). (S. Satyanegara, Ed.). Jakarta: Arcan.

Zhao X, Jiang Y, Zhao Y, Xi H, Liu C, Qu F, Feng X. (2020). Analysis of the susceptibility to COVID-19 in pregnancy and recommendations on potential drug screening. Eur J Clin Microbiol Infect Dis. 39(7). doi. https://doi.org/10.1007/s10096-020-03897-6. 